\title{
PAGINA DEL DECANO
}

\author{
Dr. Waldo Callo Villa
}

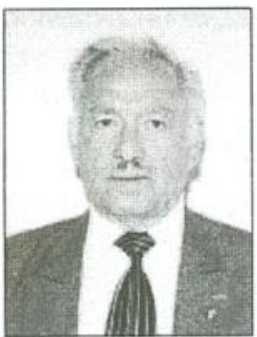

Desde que el hombre ha hecho conciencia que su salud debe tener un cuidado especial y debe recurrir a terceras personas, ha pasado mucha agua bajo el puente.

Quien dio las pautas para los que deseaban CURAR o SANAR, a sus semejantes, tomando las debidas precauciones y además se capacitaran para ello, fue el maestro HIPÓCRATES.

La escuela de Cos, fue la que dio las pautas de una adecuada formación y atención medica y también dio recomendaciones para un comportamiento en el acto que realizaban, ahora llamado "acto médico".

Han pasado tres mil trescientos años desde aquella vez, y el médico, a quien antes de la era hipocrática, lo temían; posteriormente fué respetado pues tenía obligaciones con sus semejantes y trataba por todos los medios posibles, conseguir que el doliente curase.

Medicina, palabra bendita, acepción que reclama un entendimiento basto y un conocimiento mayor de quien la practica, que con el correr de los años las exigencias para su estudio son mayores y ahora son muchísimo mas que hace medio siglo.

La enseñanza clásica, de la clase magistral y las practicas clínicas, exigentes y a dedicación exclusiva, son ahora, no reemplazadas, sino apoyadas por el aporte de la tecnología de punta que a diario se descubre o encuentra.

Pero no sólo es ello, es también que el profesor o el profesional del hospital o la clínica debe ponerse al día con los adelantos en conocimientos, que cada vez son mayores y por supuesto los alumnos deberán ponerse a tono con ello.

Eso ocurre en un país, donde el gobierno se preocupa porque la salud y el bienestar de la población esté basado en un PRESUPUESTO ADECUADO y dirigido a invertir en una mejor enseñanza aprendizaje desde los niveles iniciales hasta los universitarios y ultra-especializados. Que el poblador tenga un algo de que vivir y qué comer, o sea TRABAJO, para afrontar las demandas de su cuidado personal y de su familia.

El presupuesto también debe contemplar que la inversión en velar por la SALUD de la población, por el mejor capital que tiene el país.

Nuestro gobierno, no invierte ni en lo uno ni en lo otro, cuida los intereses de entidades foráneas a las que no les interesa la salud de una nación tercermundista. Total, ganar dinero fácil es lo que ellos quieren. .

Frente a esas circunstancias, que puede exigirse a los profesionales de la salud, en especial los MEDICOS, que deban financiar un SEGURO MEDICO, para reponer económicamente por los problemas que pudieran suceder por un acto médico, y que por mala praxis (mal interpretada), no demostrada, enjuiciarlo, denostarlo, sancionarlo, etc.

Tengamos presente, que para poder exigir, hay que hacerlo ante quienes corresponda, que el personal de salud, tenga la infraestructura e implementación adecuada y haya suficiente número de los mismos para que puedan atender a los que reclamen de ella.

Todos conocemos las infraestructuras de nuestros servicios de salud, también las limitaciones que se nos pone para realizar determinado tipo de atenciones y muchas otras cosas mas que son de dominio publico. Frente a ello, que podemos hacer, debemos pagar un seguro que irá a engrosar las arcas de quien sabe qué grupos interesados y qué seguros cubrirán????

Eso quieren hacer con los médicos, expoliarlos sin razón.

Por lo tanto, la entidad que debe pagar dicho seguro debe ser la Institución donde labora el profesional, pues es en ese lugar y por causa de falencias de materiales e insumos en la gran mayoría de veces se producen los reclamos por "negligencia". 